\title{
Pengaruh Faktor Lingkungan terhadap Produktivitas Telur Ayam Kampung Unggulan Balitbangtan (KUB) Fase Layer
}

\author{
The Effect of Environmental Factors on The Productivity of Kampong Chicken Eggs \\ Balitbangtan (KUB) Layer Phase
}

\author{
Fidi Nur Aini Eka Puji Dameanti ${ }^{1 *}$, Muhammad Aviv Firdaus ${ }^{2}$, Nurina Titisari ${ }^{1}$, Siska \\ Aditya $^{1}$, Ignatius Guritno ${ }^{3}$ \\ ${ }^{1}$ Fakultas Kedokteran Hewan, Universitas Brawijaya, ${ }^{2}$ Mahasiswa Sarjana Fakultas Kedokteran Hewan, \\ Universitas Brawijaya, ${ }^{3}$ Balai Besar Pelatihan Peternakan (BBPP) Batu \\ *Corresponding author: fididameanti88@gmail.com
}

\begin{abstract}
Abstrak
Kecepatan angin, pencahayaan, kelembaban dan suhu merupakan faktor lingkungan yang berpengaruh dalam produksi telur. Ayam KUB atau Ayam Kampung Unggulan Balitbangtan adalah strain ayam petelur baru yang mempunyai kemampuan maksimal dalam berproduksi. Penelitian ini bertujuan untuk melihat seberapa besar pengaruh kecepatan angin, pencahayaan, kelembaban, dan suhu terhadap produktivitas telur Ayam KUB fase layer pada umur minimal 43 minggu. Data diperoleh dengan desain penelitian cross-sectional melalui pengukuran dan perhitungan terhadap data populasi. Rata-rata faktor lingkungan berupa kecepatan angin, pencahayaan, kelembaban dan suhu adalah secara berurutan yaitu $1.46 \mathrm{~m} / \mathrm{s}, 17.53 \mathrm{lux}, 72.11 \%$, dan $27.71^{\circ} \mathrm{C}$. Produktivitas telur Ayam KUB Petelur umur 43-46 minggu adalah 66.11\%. Seluruh faktor lingkungan secara bersama-sama memberikan pengaruh sebesar $31.4 \%$ terhadap produktivitas telur Ayam KUB.
\end{abstract}

Kata kunci: ayam KUB, faktor lingkungan, produktivitas telur

\begin{abstract}
Wind speed, lighting, humidity, and temperature are the main factors affecting egg production. Chicken KUB or Kampung Unggulan Balitbangtan Chicken is a new laying hen strain with full production capability. The aim of this research was to determine the effect of environmental factors i.e. wind speed, lighting, humidity, and temperature on the productivity of chicken eggs Kampung unggulan Balitbang (KUB) layer phase at 43 weeks. In this research, the data obtained by cross-sectional research design through measurement and calculation of population data.In result, the average environmental factors in the form of wind speed, lighting, humidity, and temperature were $1.46 \mathrm{~m} / \mathrm{s}, 17.53 \mathrm{lux}, 72.11 \%$, and $27.71^{\circ} \mathrm{C}$. The egg productivity of chicken KUB Laying at 43-46 weeks is $66.11 \%$. All environmental factors together give an effect of $31.4 \%$ on the productivity of Chicken eggs KUB.
\end{abstract}

Keywords: KUB chicken, environmental factor, egg productivity

Received: 23 Juni 2020

Revised: 3 Juli 2020

Accepted: 11 Agustus 2020

\section{PENDAHULUAN}

Ayam layer merupakan ternak unggas yang cukup potensial di Indonesia. Ayam layer dibudidayakan khusus untuk menghasilkan telur secara komersial. Kebutuhan telur konsumsi nasional semakin meningkat setiap tahun (Setiawati dkk., 2016). Telur konsumsi dari ayam ras hanya mampu memenuhi 65\% kebutuhan telur nasional, dan sisanya dipasok telur ayam kampung, itik dan puyuh (Kementan,
2018). Produksi telur rata-rata ayam kampung umumnya, mencapai $20 \%$ (73 butir per tahun per ekor) pada pemeliharaan semi intensif dan sekitar 30\% (110 butir per tahun per ekor) pada pemeliharaan intensif (Iskandar, 2010). Produksi ini jauh dari produksi yang dimiliki oleh ayam ras, guna meningkatkan produksi telur ayam kampung, pemerintah beserta Peneliti Indonesia berkolaborasi dengan menciptakan strain ayam baru yakni (Ayam KUB atau Ayam Kampung Unggulan Balitbangtan) yang telah dilakukan 
penelitian lebih dari 5 tahun dengan hasil data menunjukkan bahwa ayam KUB umur 70 hari beratnya mencapai $1 \mathrm{~kg}$; umur pertama bertelur 20-22 minggu dengan bobot badan antara 1.2-1.6 $\mathrm{kg}$; produksi telur 16-180 butir/ekor/tahun; produksi telur sekitar 50 persen; puncak produksi telur mencapai 65-70 persen; dan lebih tahan terhadap penyakit (Aditya, 2019).

Faktor utama yang berpengaruh dalam produksi telur adalah faktor genetik dan faktor lingkungan (Goto et al., 2019). Ayam KUB secara genetis merupakan ayam yang mempunyai kemampuan maksimal dalam berproduksi. Ayam KUB Petelur dewasa atau fase layer ada di umur 18-68 minggu (Cybext, 2019). Umur 43 minggu merupakan umur pertengahan Ayam KUB fase layer. Kondisi lingkungan yang baik dan sesuai akan mampu menunjang produktivitas ayam KUB petelur. Kondisi lingkungan yang menjadi perhatian diantaranya adalah kecepatan angin, pencahayaan, kelembaban, dan suhu, berdasarkan kondisi diatas, peneliti tertarik untuk melakukan penelitian guna melihat seberapa besar pengaruh lingkungan (kecepatan angin, pencahayaan, kelembaban, dan suhu) terhadap produktivitas telur Ayam KUB fase layer pada umur minimal 43 minggu.

\section{METODE PENELITIAN}

Penelitian dilaksanakan di Balai Besar Pelatihan Peternakan Batu, Jawa Timur pada bulan Januari-Februari 2020. Penelitian ini merupakan desain penelitian cross-sectional, dengan variabel penelitian yang digunakan adalah variabel bebas berupa faktor lingkungan yaitu kecepatan angin, pencahayaan, kelembaban, dan suhu serta variabel terikat produktivitas telur.

Data faktor lingkungan berupa kecepatan angin diperoleh dari pengukuran menggunakan alat berupa Anemometer dimana pengukuran dilakukan 2 kali dalam sehari yaitu saat pagi dan sore dalam waktu yang sama setiap harinya. Pencahayaan diukur dengan menggunakan Luxmeter yang diukur sebanyak 4 kali dalam sehari yaitu saat pagi, siang, sore, dan malam dalam waktu yang sama setiap harinya. Kelembaban dan suhu lingkungan diukur dalam satu waktu yang bersamaan setiap pagi dan sore menggunakan Thermohygrometer. Produktivitas telur mengacu pada persen Hen Day Production (HDP) yaitu persentase perbandingan jumlah telur yang diperoleh pada hari itu dibagi dengan jumlah ayam yang hidup pada hari itu.

Subjek penelitian yang digunakan pada penelitian ini adalah populasi Ayam KUB fase layer yang berjumlah 44 ekor dengan kriteria inklusi yaitu berumur pada akhir masa produksi yaitu minimal 43 minggu pada saat awal pengamatan.

Data variabel bebas dan terikat yang terkumpul diinput pada software Microsoft Excel 2010 untuk dilakukan cleaning data kemudian dilakukan uji statistik dengan menggunakan SPSS 16.0 untuk menguji pengaruh dari variabel bebas terhadap variabel terikat. Uji asumsi klasik dilakukan sebelum melakukan uji regresi berganda antara lain berupa uji normalitas, linieritas, multikolinieritas, heteroskedastisitas, dan autokorelasi (Duli, 2019). Hasil data pengujian regresi berganda disajikan dalam bentuk tabel dan grafik untuk dilakukan pembahasan.

\section{HASIL DAN PEMBAHASAN}

Faktor lingkungan seperti perkandangan menjadi salah satu aspek pokok yang perlu diperhatikan dalam pemeliharaan ayam petelur yang intensif dan efisien (Amijaya dkk., 2018). Peternakan Ayam KUB fase layer di BBPP Batu merupakan peternakan yang menggunakan tipe perkandangan tertutup (clouse house) dengan sistem litter atau postal yang memiliki luas kandang sebesar $15 \mathrm{~m}^{2}$. Kandang dilengkapi dengan tempat pakan berbentuk setengah lingkaran, tempat minum (nipple), alat penerangan yang cukup, exhaust fan, colling pad, plafon, dan tirai. Sistem perkandangan ini mengadopsi sistem yang diterapkan untuk ayam kampung petelur.

Sistem pemeliharaan Ayam KUB fase layer ini sesuai dengan pendapat Hayanti (2014), yang menyatakan bahwa sebaiknya Ayam KUB fase 
Tabel 1. Nilai rata-rata faktor lingkungan dan produktivitas telur

\begin{tabular}{lc}
\hline \multicolumn{1}{c}{ Keterangan } & Rata-rata \\
\hline Kecepatan Angin $(\mathrm{m} / \mathrm{s})$ & 1.46 \\
Pencahayaan $($ Lux $)$ & 17.53 \\
Kelembaban $(\%)$ & 72.11 \\
Suhu $\left({ }^{\circ} \mathrm{C}\right)$ & 27.71 \\
Produktivitas Telur $(\%)$ & 66.11 \\
\hline
\end{tabular}

Tabel 2. Pengaruh faktor lingkungan terhadap produktivitas telur ayam KUB petelur

\begin{tabular}{lccc}
\hline \multirow{2}{*}{ Keterangan } & \multicolumn{3}{c}{ Produktivitas Telur } \\
\cline { 2 - 4 } & Koefisien Regresi & $\boldsymbol{p}$-value & $\mathbf{R}^{\mathbf{2}}$ \\
\hline Konstanta & 95.627 & & \\
Kecepatan Angin & 23.449 & 0.015 & \\
Pencahayaan & 0.056 & 0.895 & \\
Kelembaban & -0.214 & 0.486 & \\
Suhu & -1.775 & 0.417 & \\
Keseluruhan & & 0.129 & 0.314 \\
\hline
\end{tabular}
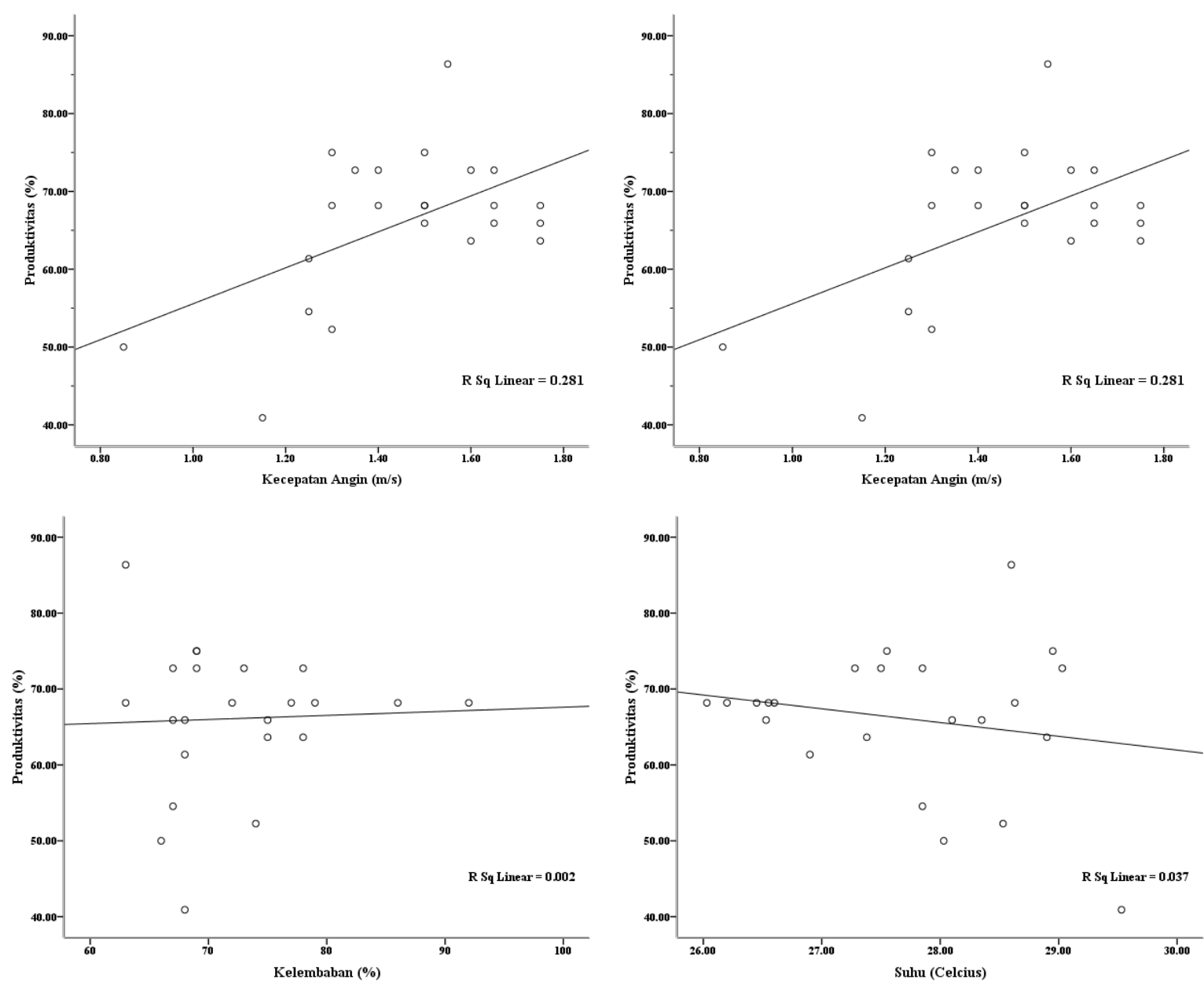

Gambar 1. Korelasi faktor lingkungan terhadap produktivitas ayam KUB fase layer

layer dipelihara dalam kadang dengan sistem postal karena dapat memberikan fasilitas Ayam KUB fase layer untuk mengeram dan melakukan aktivitas seperti halnya ayam kampung biasanya, sehingga diharapkan dapat meminimalisasi pengaruh stres kandang dari kondisi lingkungan 
atau perubahan iklim diluar kandang. Penggunaan kandang clouse house sistem postal ini bertujuan untuk mengendalikan faktor kecepatan angin, pencahayaan, kelembaban, dan suhu di dalam kandang sehingga dapat memaksimalkan produksi telur (Sujana dkk., 2011; Rahmaningtyas dkk., 2017).

Kondisi rata-rata faktor lingkungan dan produktivitas telur selama pengamatan di peternakan Ayam KUB fase layer di BBPP Batu tersaji dalam Tabel 1. Sedangkan pengaruh faktor lingkungan terhadap produktivitas telur tersaji dalam Tabel 2.

\section{Kecepatan Angin}

Kecepatan angin adalah salah satu bagian mikroklimat kandang yang memiliki peran sangat penting dalam respon ternak (Amijaya dkk., 2018). Tabel 1 menunjukkan bahwa ratarata kecepatan angin selama periode pengamatan adalah $1.46 \mathrm{~m} / \mathrm{s}$. Nilai ini sedikit berada di atas nilai rata-rata kecepatan angin pada penelitian yang dilakukan oleh Amijaya dkk. (2018), dimana rata-rata kecepatan angin dalam kandang clouse house adalah sebesar $1.3 \mathrm{~m} / \mathrm{s}$. Nilai ratarata kecepatan angin tersebut masih dalam kondisi cukup baik. Kecepatan angin yang baik dan sesuai dengan kondisi kandang akan mampu menjaga kondisi suhu kandang dan dapat menurunkan heat stress pada ayam, sehingga dapat meningkatkan produktivitas telur pada ayam (Yani dkk., 2014), hal ini terbukti secara statistik bahwa secara parsial, kecepatan angin memiliki nilai $p<0.05$ (Tabel 2) dimana memiliki arti bahwa kecepatan angin memberikan pengaruh yang signifikan terhadap produktivitas telur pada Ayam KUB fase layer umur 43-46 minggu. Kondisi ini sejalan dengan penelitian yang dilakukan oleh Nuriyasa dan Astiningsih (2002), dimana kandang dengan kecepatan angin lebih rendah menjadi kondisi kurang nyaman untuk ayam sehingga menyebabkan frekeuensi ayam ke tempat makan lebih sering namun waktu makan lebih cepat. Ayam pada kandang yang tidak nyaman tersebut mengalami heat stress sehingga memerlukan energi lebih banyak untuk maintenance dan produksi, hal ini menyebabkan produktivitas ayam pada kandang angin rendah lebih sedikit jika dibandingkan dengan produktivitas ayam pada kandang dengan angin yang lebih tinggi (Nuriyasa dan Astiningsih, 2002).

\section{Pencahayaan}

Cahaya berfungsi dalam proses penglihatan, merangsang siklus internal dan menstimulasi pelepasan hormon (Sangi, 2017). Hormon yang berhubungan dengan cahaya antara lain yaitu hormon FSH dan LH yang akan mempengaruhi proses ovulasi (Kasiyati, 2018). Rata-rata pencahayaan pada saat pengamatan adalah 17.53 lux. Nilai ini dalam kisaran pencahayaan yang baik untuk ayam petelur fase produksi. Kustiawan dkk. (2019) menyebutkan bahwa ayam petelur fase produksi sebaiknya diberi pencahayaan yang baik dengan intensitas cahaya 10-20 lux, namun nilai rata-rata tersebut masih belum memberikan pengaruh yang signifikan secara statistik ( $p$-value >0.05) (Tabel 2). Penelitian ini menunjukkan bahwa secara parsial, pencahayaan tidak memberikan pengaruh yang signifikan terhadap produktivitas telur pada Ayam KUB fase layer umur 43-46 minggu, hal ini dapat dikarenakan intensitas cahaya pada kandang Ayam KUB fase layer tersebut lebih besar dari 15 lux. Penelitian yang dilakukan oleh Kustiawan dkk. (2019) menunjukkan bahwa pada umur menjelang akhir produksi (38 minggu) penggunaan intensitas pencahayaan 15 lux dapat meningkatkan efisiensi produksi.

\section{Kelembaban}

Nilai rata-rata kelembaban selama periode pengamatan adalah sebesar $72.11 \%$, yang mana termasuk dalam kategori kelembaban tinggi. Menurut Purwanto dan Yani (2006) kelembaban optimal pada kandang berkisar antara 55-65\%, sedangkan menurut Nurcholis dkk. (2009), kelembaban optimal untuk ayam petelur berkisar antara $60 \%$. Penelitian yang dilakukan oleh Kirunda et al., (2001) menyebutkan bahwa kelembaban diatas $60 \%$ akan menyebabkan penurunan produksi telur sebanyak $4.16 \%$. Penelitian ini sejalan dengan penelitian Kirunda et al., (2001), dimana konstanta pada variabel kelembaban menunjukkan nilai negatif $(-0.214)$ 
yang artinya bahwa kelembaban $72.11 \%$ akan mengurangi produktivitas telur Ayam KUB fase layer, namun kondisi tersebut secara parsial tidak memiliki pengaruh yang signifikan terhadap produktivitas telur Ayam KUB fase layer karena nilai $p$ yang lebih besar dari 0.05 yaitu 0.486. Rukhyat dan Edjeng (2006) juga menyatakan bahwa apabila kelembaban tidak sesuai, maka ayam layer akan memberi feedback negatif berupa penurunan produksi baik dari segi kualitas maupun kuantitas telur. Kelembaban yang tinggi menyebabkan terjadinya masalah pernafasan pada ayam karena berpengarh pada penyerapan gas amonia (Nurcholis dkk., 2009; Kartikasari dkk., 2019). Kandungan gas amonia yang tinggi mengganggu ayam dalam pengambilan oksigen sehingga akan mengganggu sistem pernafasan dan metabolisme yang akan berdampak pada kemampuan ayam layer untuk bertelur (Mardalena, 2002).

\section{Suhu}

Suhu merupakan salah satu faktor penting dalam perkandangan karena sebagai controling factor yang dapat mempengaruhi aktivitas fisiologis dan biokimia ternak (Sari dkk., 2017). Rata-rata suhu kandang selama pangamatan adalah $27.8^{\circ}$ C. Menurut Kilic dan Simsek (2013) dan Setiawati dkk. (2016), suhu kandang yang dapat membuat ayam merasa nyaman yakni 18$28^{\circ} \mathrm{C}$. Selama periode pengamatan suhu kandang berada dalam kondisi yang membuat ayam merasa nyaman, akan tetapi kondisi ini tidak memberikan pengaruh yang signifikan secara parsial terhadap produktivitas telur Ayam KUB fase layer $\quad(p$-value $=0,417) . \quad$ Kondisi ini membuktikan penelitian yang dilakukan oleh Setiawati dkk. (2016) dimana ayam petelur memiliki performa produksi lebih baik dengan suhu netral $\left(18^{\circ} \mathrm{C}\right)$.

\section{Keseluruhan}

Rata-rata produktivitas telur selama pengamatan (umur 43-46 minggu) adalah $66.11 \%$. Nilai ini sesuai dengan Hayanti (2014), dimana prosentase produksi telur Ayam KUB dengan pemeliharaan secara intensif adalah sebesar $44-70 \%$. Uji statistik menunjukkan bahwa faktor lingkungan memberikan pengaruh sekitar 31.4\% $\left(\mathrm{R}^{2}=0.314\right)$ dengan persamaan yang tersaji adalah $\mathrm{Y}=95.627+23.449 \mathrm{X}_{1}+$ $0.056 \mathrm{X}_{2}-0.214 \mathrm{X}_{3}-1.775 \mathrm{X}_{4}$. Dimana $\mathrm{Y}$ merupakan nilai produktivitas, $\mathrm{X}_{1}$ adalah kecepatan angin, $X_{2}$ adalah pencahayaan, $X_{3}$ adalah kelembaban, dan $\mathrm{X}_{4}$ adalah suhu. Persamaan tersebut secara statistik tidak memberikan arti yang signifikan karena $p$-value $>0.05$. Grafik untuk korelasi antara setiap faktor lingkungan (kecepatan angin, pencahayaan, kelembaban dan suhu) dengan produktivitas ayam layer tersaji dalam Gambar 1.

\section{KESIMPULAN}

Rata-rata faktor lingkungan berupa kecepatan angin, pencahayaan, kelembaban dan suhu adalah secara berurutan yaitu $1.46 \mathrm{~m} / \mathrm{s}$, 17.53 lux, $72.11 \%$, dan $27.71^{\circ} \mathrm{C}$. Produktivitas telur Ayam KUB fase layer umur 43-46 minggu adalah $66.11 \%$. Walaupun tidak signifikan, faktor lingkungan secara bersama-sama memberikan pengaruh sebesar $31.4 \%$, secara parsial faktor lingkungan berupa kecepatan angin memberikan pengaruh yang siginfikan terhadap produktivitas telur, sedangkan pencahayaan, kelembaban dan suhu tidak memberikan pengaruh yang signifikan terhadap produktivitas telur Ayam fase layer.

\section{UCAPAN TERIMA KASIH}

Peneliti mengucapkan terimakasih kepada Balai Besar Pelatihan Peternakan Batu dan Fakultas Kedokteran Hewan Universitas Brawijaya atas izin yang telah diberikan untuk melakukan penelitian.

\section{DAFTAR PUSTAKA}

Aditya, T.D. 2019. Teknologi Budidaya Ayam Kampung Unggul Balitbangtan (KUB).

Amijaya, D,T., Yani, A., Rukmiasih. 2018. Performa ayam ras petelur pada letak cage berbeda dalam sistem cloused house di Global Buwana Farm. Jurnal Ilmu Produksi 
dan Teknologi Hasil Peternakan, 6(3), 98103.

Cybext. 2019. Budidaya Ayam KUB.

Duli, N. 2019. Metodologi Penelitian Kuantitatif: Beberapa Konsep Dasar untuk Penulisan Skripsi \& Analisis Data dengan SPSS. Yogyakarta: Deepublish Publisher, Hal: 114-126.

Goto, T., Mori, H., Shiota, S., Tomonaga, S. 2019. Metabolomics approach reveals the effects of breed and feed on the composition of chicken eggs. Metab., 9(224), 1-12.

Hayanti, S.Y. 2014. Petunjuk Teknis Budidaya Ayam Kampung Unggul (KUB) Badan Litbang Pertanian di Provinsi Jambi. Jambi: Penerbit Balai Pengkajian Teknologi Pertanian Jambi, Hal: 1-14.

Iskandar, S. 2010. Usahatani Ayam Kampung. Bogor: Balai Penelitian Ternak Ciawi, Hal: 1-6.

Kartikasari, A.M., Hamid, I.S., Purnama, M.T.E., Damayanti, R., Fikri, F., Praja, R.N. 2019. Isolasi dan identifikasi bakteri Escherichia coli kontaminan pada daging ayam broiler di rumah potong ayam Kabupaten Lamongan. Jurnal Medik Veteriner, 2(1), 66-71.

Kasiyati. 2018. Peran cahaya bagi kehidupan unggas: respons pertumbuhan dan reproduksi. Buletin Anatomi dan Fisiologi, 3(1), 116-125.

Kementerian Pertanian. 2018. Konsumsi telur ayam ras diprediksi mencapai 1,72 juta ton pada 2021.

Kilic, I., Simsek, E. 2013. The effects of heat stress on egg production and quality of laying hens. J. Anim. Vet. Adv., 12(1), 4247.
Kirunda, D.F., Scheideler, S.E., Mckee, S.R. 2001. The efficacy of vitamin e (dl- $\alpha$ tocopheryl acetate) supplementationin hen diets to alleviate egg quality deterioration associatedwith high temperature exposure. Poult. Sci., 80(9), 1378-1383.

Kustiawan, E., Rukmi, D.L., Imam, S., Permadi, S.O. 2019. Studi intensitas pencahayaan terhadap puncak produksi ayam petelur fase layer di UD. Mahakarya Farm Banyuwangi. Jurnal Ilmu Peternakan Terapan, 3(1), 14-18.

Mardalena. 2002. Pengaruh jenis alas kandang terhadap bobot karkas ayam broiler jantan. Jurnal Ilmiah Ilmu-ilmu Peternakan, 5(2), 89-94.

Nuriyasa, I.M., Astiningsih, N.K. 2002. Pengaruh tingkat kepadatan ternak dan kecepatan angin dalam kandang terhadap tabiat makan ayam pedaging. Majalah Ilmiah Peternakan, 5(3), 99-103.

Nurcholis, Hastuti, D., Sutiono, B. 2009. Tatalaksana pemeliharaan ayam ras petelur periode layer di Populer Farm Desa Kuncen Kecamatan Mijen Kota Semarang. Jurnal Ilmu-ilmu Peternakan (MEDIAGRO), 5(2), 38-49.

Purwanto, B.P., Yani, A. 2006. Pengaruh iklim mikro terhadap respon fisiologis sapi peranakan Fries holland dan modifikasi lingkungan untuk meningkatkan produktivitasnya. Med. Pet., 29(1), 35-46.

Rahmaningtyas, I.H., Yulianto, R., Prastika, D.W., Arifin, K., Oktaviana, V., Setiabudi, R.S., Purnama, M.T.E. 2017. Efektivitas tepung teritip (cirripedia sp) terhadap pertambahan berat badan dan feed convertion ratio (fcr) ayam pedaging. Surabaya. Jurnal Agro Veteriner Universitas Airlangga, 5(2). 
Rukhyat, K., Edjeng, S. 2006. Manajemen Ternak Unggas. Bandung: Penebar Swadaya, Hal: 53-78.

Sangi, J., Saerang, J.L.P., Nangoy, F., Laihad, J. 2017. Pengaruh warna cahaya lampu terhadap produksi telur buurng puyuh. Jurnal Zootek, 37(2), 224-231.

Sari, O., Bambang, P., Nur, R.U. 2012. Suhu, kelembaban, serta produksi telur itik pada kandang tipe litter dan slat. Unnes J. Life Sci., 1(2), 94-100.

Setiawati, T., Afnan, R., Ulupi, N. 2016. Performa produksi dan kualitas telur ayam petelur pada sistem litter dan cage dengan suhu kandang berbeda. Jurnal Ilmu Produksi dan Teknologi Hasil Peternakan, 4(1), $197-$ 203.

Sujana, E., Darana, S., Setiawan, I. 2011. Implementasi teknologi semi closed-house system pada performa ayam broiler di test farm sustainable livestock technopark. Bogor, 7-8 Juni 2011. Hal: 362-364.

Yani, A., Suhardiyanto, H., Erizal, Ourwanto, B.P. 2014. Analysis of air temperature distribution in a closed house for broiler in wet tropical climate. Med. Pet., 37(2), 87-94. 